\title{
Production of kombucha tea as alternative source of probiotic drink in Mandailing sub-district Tebing Tinggi City
}

\author{
Andy Candra ${ }^{1 *}$, Fasihah Irfanii Fitri $^{2}$, Dina Nazriani ${ }^{3}$, Siti Utari Rahayu ${ }^{1}$ \\ ${ }^{1}$ Faculty of of Mathematics and Natural Science, Universitas Sumatera Utara \\ ${ }^{2}$ Faculty of Medicines, Universitas Sumatera Utara \\ ${ }^{3}$ Faculty of Psychology, Universitas Sumatera Utara \\ *Email: andch3n@usu.ac.id
}

\begin{abstract}
Kombucha is a well-known health probiotic drink. Kombucha was first used in East Asia (Manchuria) in the Tsin Dynasty around $220 \mathrm{BC}$ which was used for detoxification. This probiotic drink is a fresh drink from a slightly sweet, slightly acidic tea that is consumed worldwide. Kombucha tea is obtained from tea leaf infusion by fermentation with SCOBY (symbiotic culture of yeast and bacteria). The taste of the fermented tea is like apple cider vinegar. With the development of The Kombucha era, it has been studied by many researchers and provides excellent health benefits including as a source of antioxidants to prevent free radicals, antibacterial, anticancer, for diabetes, cardiovascular (heart disease), digestive problems and low body immunity because age factor. In the Mandailing sub-district, Tebing Tinggi city, there is a lack of public awareness of health. With the training in making kombucha probiotic drink, it is hoped that residents in that area can apply this health drink to improve a healthy lifestyle.
\end{abstract}

Keyword: Kombucha, probiotic drink, health

\begin{abstract}
Abstrak
Kombucha merupakan minuman probiotik kesehatan yang sudah sejak lama dikenal. Kombucha pertama kali digunakan di Asia Timur (Manchuria) pada Dinasti Tsin kira kira 220 SM yang digunakan untuk detoksifikasi. Minuman probiotik ini merupakan minuman segar dari teh yang sedikit manis, sedikit asam yang dikonsumsi diseluruh dunia. Teh Kombucha diperoleh dari infuse daun teh dengan fermentasi dengan SCOBY (simbiotik kultur dari ragi dan bakteri). Rasa dari teh fermentasi tersebut seperti cuka apel. Dengan berkembanganya zaman The Kombucha sudah diteliti oleh banyak peneliti dan memberikan manfaat yang sangat baik bagi kesehatan diantaranya: sebagai sumber antioksidan untuk mencegah radikal bebas, antibakteri, antikanker, untuk penyakit diabetes, kardiovaskular (penyakit jantung), masalah pencernaan dan imunitas tubuh yang rendah karena faktor usia. Di kelurahan Mandailing kota Tebing Tinggi terdapat kurangnya kesadaran pada masyarakat akan kesehatan. Dengan adanya pelatihan pembuatan minuman probiotik kombucha ini diharapkan warga setempat dapat mengaplikasikan minuman kesehatan ini untuk meningkatkan pola hidup sehat.
\end{abstract}

Kata Kunci: Kombucha, minuman probiotik, kesehatan

\section{PENDAHULUAN}

Menurut World Health Organization (WHO), terdapat beberapa faktor yang mempengaruhi kepatuhan pengobatan diantaranya yaitu umur, jenis kelamin, tingkat pendidikan, status pekerjaan, lama menderita hipertensi, lama pengobatan hipertensi, tingkat pengetahuan, motivasi pengobatan, efek samping obat, persepsi pelayanan kesehatan, dan dukungan keluarga. Kepatuhan pengobatan adalah salah satu kunci keberhasilan pengobatan hipertensi, namun kepatuhan pengobatan masih menunjukkan angka yang rendah. Di Cina, Gambia, dan Seychelles, masing-masing hanya 43\%, 27\%, 
Andy Candra et.al. Production of kombucha tea as alternative source of probiotic drink

dan $26 \%$ penderita hipertensi yang mematuhi pengobatan dengan antihipertensi. Di negara maju, seperti Amerika Serikat bahkan hanya 51\% dari penderita yang dirawat yang mematuhi pengobatan (WHO, 2003). Berdasarkan Riskesdas tahun 2018, proporsi pengobatan hipertensi di Indonesia belum mencapai target $100 \%$. Adapun proporsi minum obat hipertensi hanya mencapai angka 54,4\%, sisanya 32,3\% tidak rutin mengkonsumsi obat, dan 13,3\% tidak mengkonsumsi obat. (Riskesdas,2018).

Kelurahan Mandailing, Kota Tebing Tinggi merupakan salah satu kelurahan di Kecamatan Mandailing Kota Tebing Tinggi yang mayoritas penduduknya tinggal di sekeliling DAS (Daerah Aliran Sungai) serta jalan yang sempit dan pemukiman yang agak kumuh terutama dilingkungan III dan IV. Kelurahan ini terletak kurang lebih $79 \mathrm{~km}$ dari USU. Dengan data puskesmas di tahun 2019 terdapat peningkatan warga yang mengidap penyakit Hipertensi dan Diabetes Melitus, serta hasil interview dengan warga banyak yang mengeluhkan kadar kolestrol dalam tubuh yang tinggi serta sanitasi di lingkungan sekitar yang kurang baik. Selama ini para warga masih kurang kesadarannya akan kesehatan dan kebersihan, salah satunya masih mencuci di DAS di sekitar rumah mereka dan kurangnya menjaga pola hidup sehat, oleh karena itu Rina Aslam, SE selaku lurah di Kelurahan Mandiling Kota Tebing Tinggi mengeluhkan hal tersebut dibarengi dengan data puskesmas setempat pada tahun 2019 terjadi peningkatan pasien yang terjangkit penyakit diabetes melitus maupun hipertensi.

Salah satu produk pangan fungsional yang banyak dikonsumsi adalah minuman probiotik. Salah satunya adalah Kombucha. Kombucha merupakan minuman kesehatan yang sangat menyegarkan yang dibuat dengan fermentasi serbuk teh dengan Scoby (symbiotic consortium of bacteria and yeast) terutama spesi bakteri yang bersifat asam. Berbagai jenis khamir (seperti: spesies Pichia, Candida, Zygosaccharomyces, Brettanomyces dan Saccharomyces) dan bakteri Acetobacter xylinum telah berhasil diidentifikasi dalam fermentasi Kombucha (Jayabalan et al., 2014). Proses pembuatan minuman ini memiliki berbagai keuntungan diantaranya sebagai antioksidan, antikanker, antidiabetes dan pada pencernaan manusia ( (Jayabalan et al., 2011; Aloulou et al., 2012; Bhattacharya et al., 2013; Banerjee et al., 2011; Chakravorty et al., 2016).

Teh Kombucha dibuat dengan menempatkan kultur kombucha (jamur teh) kedalam larutan gula selama fermentasi. Jika kultur kombucha ditumbuhkan dengan resep standar menggunakan teh hitam dan diberi gula, maka substrat ini akan berubah menjadi minuman menyegarkan dengan nilai nutrisi dan kesehatan yang tinggi. (Loncar, et.al; 2000). Oleh sebab itu, tim pengusul mengajukan penyuluhan kesehatan dan pembuatan teh fermentasi kombucha yang dapat digunakan sebagai alternatif minuman probiotik untuk meningkatkan imun tubuh, menurunkan kadar kolestrol dan hipertensi yang mana diharapkan minuman probiotik ini dapat meningkatkan pola hidup sehat masyarakat.

\section{METODE PELAKSANAAN}

Teh fermentasi Kombucha dapat dibuat dengan menggunakan bubuk teh hitam, madu, aquadest, starter kombucha dan scoby. Pembuatannya: Dipanaskan aquadest sebanyak 1 L yang telah dimasukkan 3 sachet bubuk teh hitam dan $100 \mathrm{~g}$ madu, kemudian dipanaskan hingga mendidih, setelah teh sudah mencapai suhu kamar, kemudian ditambahkan starter kombucha dan scoby kemudian difermentasi selama 14 hari lalu diukur tingkat keasamannya dengan menggunakan $\mathrm{pH}$ meter dan kadar alkoholnya dengan menggunakan alkoholmeter. Berdasarkan permasalahan yang telah diidentifikasi pada mitra, metode pelaksanaan yang akan dilakukan adalah sosialisasi, pelatihan pembuatan teh kombucha dengan cara fermentasi dan pengaplikasikan minuman kesehatan tersebut sehari hari setelah fermentasi, dan pendampingan. Secara rinci, langkah-langkah yang akan dilakukan oleh perguruan tinggi pembina bersama mitra sebagai berikut:

1. Memberikan sosialisasi dan penyuluhan tentang pembuatan teh fermentasi kombucha.

2. Memberikan pretest dan posttest tentang materi teh fermentasi kombucha.

3. Membuat teh kombucha dan diaplikasikan dalam kehidupan sehari hari. 


\section{HASIL DAN PEMBAHASAN}

Kegiatan pengabdian "Pembuatan Teh Kombucha sebagai Alternatif Minuman Probiotik bagi Warga di Kelurahan Mandailing Kota Tebing Tinggi" dilakukan untuk meningkatkan pengetahuan mitra dan masyarakat sekitar mitra mengenai manfaat probiotik dan cara pembuatan teh kombucha. Untuk mendapatkan data mengenai hal tersebut kami memberikan tes sebelum dan sesudah pelaksanaan program. Tes dibuat sendiri oleh tim pengabdian berdasarkan kerangka pelaksanaan program pengabdian. Setiap peserta dalam program pengabdian memiliki 2 kali kesempatan untuk mengerjakan tes. Hasil analisis deskriptif disajikan pada Tabel 3.1

\begin{tabular}{ccc}
\hline & N & Skor Rata Rata \\
\hline Test Awal & 20 & 38.83 \\
\hline Test Akhir & 20 & 82.73 \\
\hline
\end{tabular}

Keterangan $\mathrm{N}=$ jumlah peserta penyuluhan

Tabel 3.1 Data Deskriptif

Berdasarkan hasil analisis diketahui bahwa rata-rata nilai pengetahuan tentang manfaat probiotik dan pembuatan teh Kombucha yang dimiliki oleh para peserta pengabdian sebelum diberikan program pengabdian adalah sebesar 38.33 dan menjadi 82.73 setelah mendapatkan program pengabdian. Berdasarkan nilai rerata dapat diketahui bahwa terjadi peningkatan nilai rata-rata pengetahuan peserta pengabdian tentang manfaat probiotik dan pembuatan teh Kombucha. Variasi nilai pengetahuan tentang manfaat probiotik dan pembuatan teh Kombucha sebelum diberi program pengabdian adalah sebesar 22.36 lebih besar daripada pada variasi nilai sesudah diberikan program pengabdian yaitu sebesar 20.63. Hal ini menunjukkan perbedaan pengetahuan antar setiap peserta pengabdian menjadi lebih sempit, yang berarti terjadi penyamaan rataan informasi yang diperoleh dari program pengabdian.

Sebelum dilakukan analisis lebih lanjut menggunakan uji t untuk memastikan bahwa informasi yang diberikan benar-benar bermanfaat membantu warga di Kelurahan Mandailing, Kota Tebing Tinggi pengetahuan yang lebih baik tentang manfaat probiotik dan pembuatan teh Kombucha maka dilakukan analisis prasyarat. Analisis distribusi normal sebelum melakukan uji t dilakukan menggunakan Shapiro-Wilk. Hasil analisis uji asumsi distribusi normal disajikan pada

Tabel 3.2

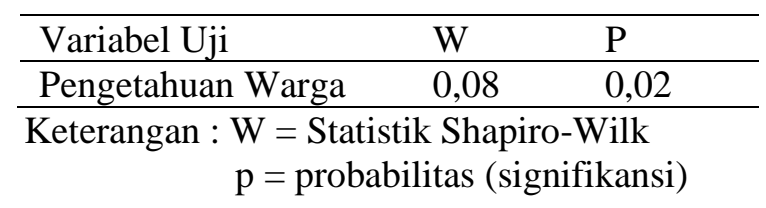

Tabel 3.2. Hasil Analisis Distribusi Normal

Berdasarkan hasil analisis yang disajikan pada Tabel 3.2 diketahui bahwa distribusi selisih nilai pada saat pretes dan post tes memiliki distribusi tidak sesuai dengan distribusi normal ; ditunjukkan dengan nilai signifikansi (p) variabel lebih kecil dari 0.05. Dengan demikian tidak dapat dilakukan pengujian lebih lanjut menggunakan uji t. Sebagai penggantinya akan dilakukan uji Wilcoxon. Hasil analisis dengan uji Wilcoxon disajikan pada Tabel 3.3

\begin{tabular}{llll}
\hline Variabel & $\mathrm{W}$ & $\mathrm{p}$ & $\mathrm{r}_{\mathrm{b}}$ \\
\hline
\end{tabular}


Andy Candra et.al. Production of kombucha tea as alternative source of probiotic drink

\begin{tabular}{rrr}
\hline Pengetahuan Warga 8,00 & $<0,001$ & 0,92 \\
\hline Keterangan W & $=$ Statistik Wilcoxon & \\
$\mathrm{P}=$ nilai signifikansi & $\mathrm{r}_{\mathrm{b}}=$ koefisien effect size \\
Tabel 3.3 Hasil Analisis Wilcoxon
\end{tabular}

Berdasarkan hasil analisis diketahui bahwa terjadinya peningkatan pengetahuan warga tentang manfaat probiotik dan pembuatan teh Kombucha dengan selisih nilai rata-rata antara sebelum dan sesudah diberi program pengabdian sebesar 44.40, adalah perbedaan yang terjadi bukan secara kebetulan pada sampel yang dilibatkan dan disimpulkan dapat saja terjadi pada semua populasi yang mungkin. Hal ini ditunjukkan dengan nilai W sebesar 8.00 dan p lebih kecil dari 0.001. Informasi tentang manfaat probiotik dan pembuatan teh Kombucha yang diberikan memberikan kontribusi sebesar 84,64\% dalam meningkatkan pengetahuan peserta terhadap manfaat probiotik dan pembuatan teh Kombucha. Berdasarkan hasil analisis ini disimpulkan bahwa program pengabdian "Pembuatan Teh Kombucha sebagai Alternatif Minuman Probiotik bagi Warga di Kelurahan Mandailing Kota Tebing Tinggi" adalah efektif dalam meningkatkan pengetahuan warga mengenai manfaat probiotik dan pembuatan teh Kombucha.

Adapun gambar produk teh kombucha yang dihasilkan dan pengabdian ini dapat ditunjukkan di gambar 3.1.

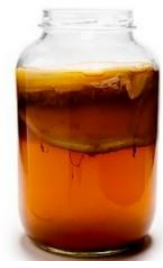

Gambar 3.1. Produk Kombucha yang dihasilkan

Masyarakat di Kelurahan Mandailing Kota Tebing Tinggi sangat antusias dalam mengikuti pelatihan dan penyuluhan dalam pembuatan teh kombucha, dengan banyaknya warga yang bertanya kepada panelis dan moderator penyuluhan.

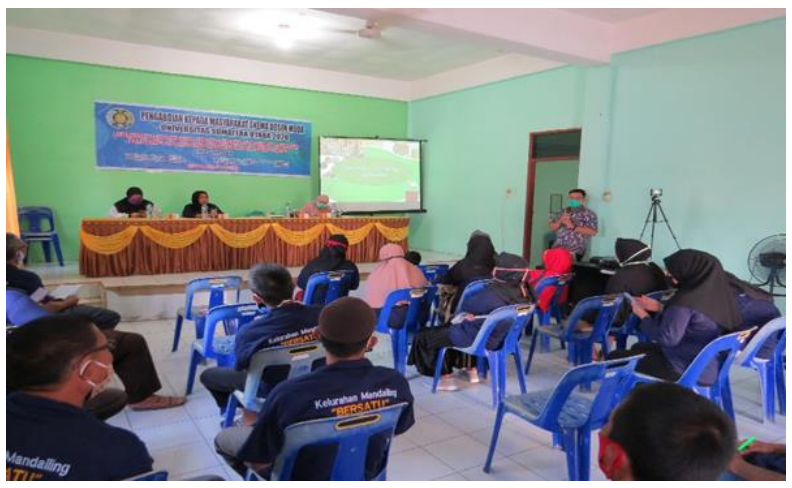

Gambar 3.2 Penyuluhan mengenai Teh Kombucha 


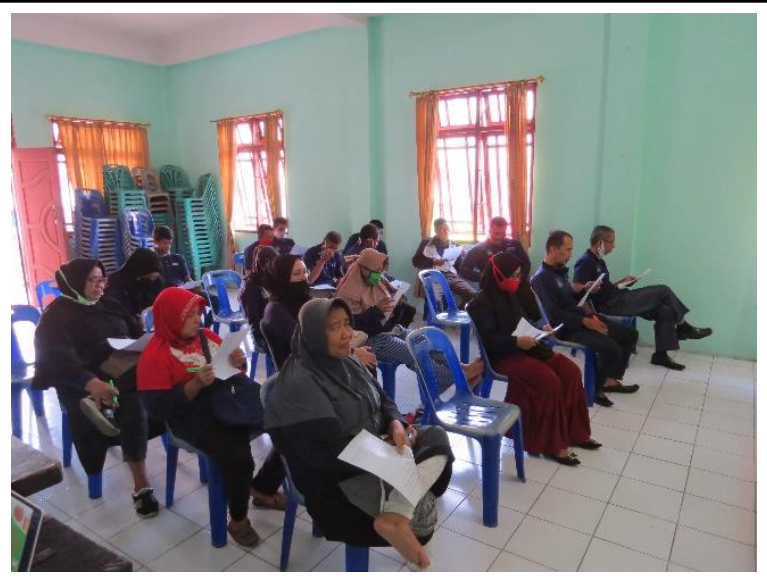

Gambar 3.3 Warga yang mengikuti Pretes dan Postest tentang Kombucha

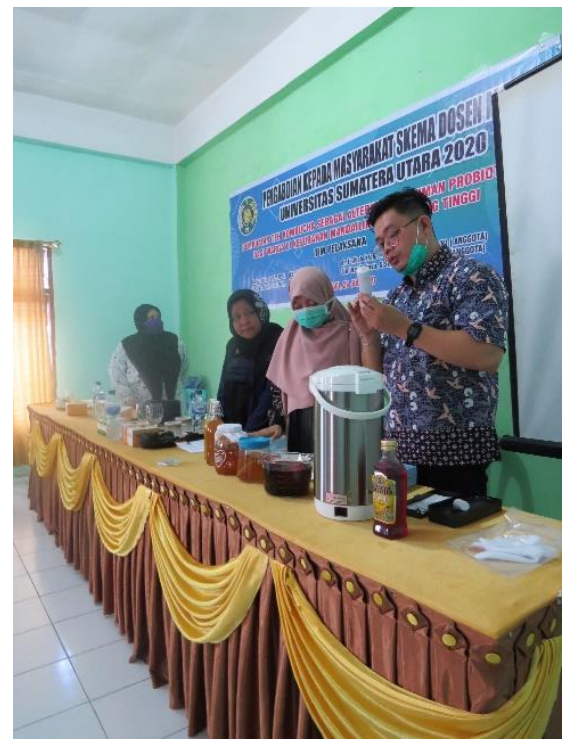

Gambar 3.4 Proses dan demonstrasi pembuatan teh Kombucha

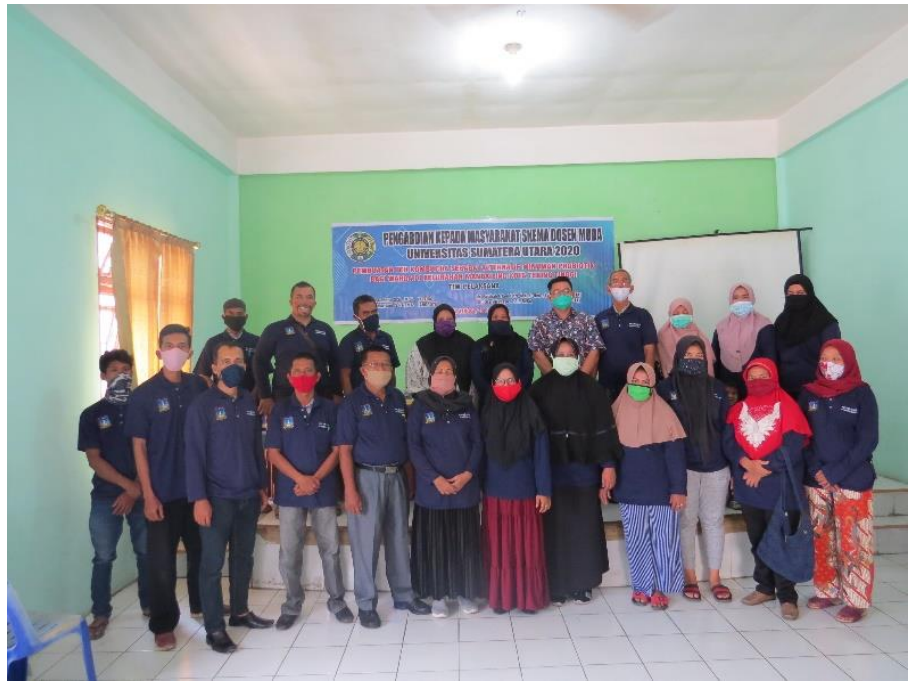


Andy Candra et.al. Production of kombucha tea as alternative source of probiotic drink

Gambar 3.5 Foto bersama dengan staf kelurahan dan warga di kelurahan Mandailing

\section{KESIMPULAN}

Penyuluhan tentang pembuatan teh kombucha sebagai alternatif minuman probiotik kesehatan di Kelurahan Mandailing kota Tebing Tinggi dapat memberikan pemahaman yang mendalam tentang pentingnya menjaga pola hidup sehat dan pentingnya minuman probiotik kesehatan Hal ini dibuktikan dengan kemampuan warga untuk mengikuti dan mengaplikasikan cara membuat minuman probiotik sesuai dengan apa yang telah diajarkan oleh pemateri dan hasil posttest yang meningkat mengenai pemahaman tentang minuman probiotik kesehatan.

\section{UCAPAN TERIMA KASIH}

Artikel ini merupakan salah satu hasil dari Program Pengabdian kepada Masyarakat yang dibiayai oleh Lembaga Pengabdian Kepada Msyarakat Universitas Sumatera Utara tahun 2020 Skema Dosen Muda. Oleh karena itu, diucapkan terima kasih kepada Rektor Universitas Sumatera Utara atas dukungan dana dan fasilitas yang diberikan. Terima kasih juga kepada Mitra pada kegiatan pengabdian ini.

Artikel ini merupakan salah satu hasil dari Program Pengabdian kepada Masyarakat Sumber Dana Non PNPB Universitas Sumatera Utara Sesuai dengan Surat Perjanjian Penugasan Pelaksanaan Program Pengabdian kepada Masyarakat Skema Dosen Muda Tahun Anggaran 2020 Nomor: 291/ UN5.2.3.2.1/ PPM /2020, Tanggal 9 Juni 2020

\section{DAFTAR PUSTAKA}

Aloulou, A., Hamden, K., Elloumi, D., Ali, M.B., Hargafi, K., Jaouadi, B., Ayadi, F., Elfeki, A., \& Ammar, E. (2012). Hypoglycemic and antilipidemic properties of Kombucha tea in alloxaninduced diabetic rats. BMC Complementary and Alternative Medicine, 12, 63-71.

Banerjee, D., Hassarajani, S.A., Maity, B., Narayan, G., Bandyopadhyay, S.K., \& Chattopadhyay, S. (2011). Comparative healing property of kombucha tea and black tea against indomethacin-induced gastric ulceration in mice: possible mechanism of action. Food and Function, 1, 284-293.

Bhattacharya, S., Gachhui, R., \& Sil, P.C. (2013). Effect of kombucha, a fermented black tea in attenuating oxidative stress mediated tissue damage in alloxan-induced diabetic rats. Food and Chemical Toxicology, 60, 328-340.

Chakravorty, S., Bhattacharya, S., Chatzinotas, A., Chakraborty, W., Bhattacharya, D., \& Gachhui, R., (2016). Kombucha tea fermentation: microbial and biochemical dynamics. International Journal of Food Microbiology. 220, 63-72.

Jayabalan, R., Chen, P.N., Hsieh, Y.S., Prabhakaran, K., Pitchai, P., Marimuthu, S., Thangaraj, P., Swaminathan, K., \& Yun, S.E., (2011). Effect of solvent fractions of kombucha tea on viability and invasiveness of cancer cells characterization of dimethyl 2-(2-hydroxy-2-methoxypropylidine) malonate and vitexin. Indian Journal of Biotechnology. 10, 75-82. 
Andy Candra et.al. Production of kombucha tea as alternative source of probiotic drink

Jayabalan, R., Malbasa, R.V., Loncar, E.S., Vitas, J.S., \& Sathishkumar, M., (2014). A review on kombucha tea-microbiology, composition, fermentation, beneficial effects, toxicity, and tea tungus. Comprehensive Review in Food Science and Food Safety. 13, 538-550.

Loncar E.S, Petrovic S.E, Malbasa R.V, \& Verac R.M., (2000). Biosynthesis of glucuronic acid by means of tea fungus. Nahrung , 44:138-9.

Departemen Kesehatan Republik Indonesia, Data Laporan Nasional Riset Kesehatan Dasar, 2018.

World Health Organization, Adherence to long term therapies, 2003. 